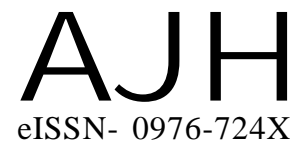

Received : 25.01.2016

Revised : 14.04.2016

Accepted : 26.04.2016
Members of the Research Forum

Associated Authors:

${ }^{1}$ Department of Horticulture, College

of Agriculture, Rajmata Vijayaraje

Scindia Krishi Vishwavidyalaya, GWALIOR (M.P.) INDIA
Author for correspondence :

MD. JAWED

Department of Horticulture, College of Agriculture, Rajmata Vijayaraje

Scindia Krishi Vishwavidyalaya,

GWALIOR (M.P.) INDIA

Email : mdjawed827@gmail.com
THEASIAN JOURNALOF HORTICULTURE

Volume $11 \mid$ Issue $1 \mid$ June, $2016|68-7|$

Visit us -www.researchjournal.co.in

\title{
Effect of foliar spray of zinc sulphate and gibberellic acid on growth and quality of guava G-27 (Psidium guajava L.)
}

\section{JAWED, R. LEKHI ${ }^{1}$, N. VASURE ${ }^{1}$, R. JATAV ${ }^{1}$ AND S. KHAN ${ }^{1}$}

ABSTRACT : A field experiment was conducted at university guava orchard, Rajmata Vijayaraje Scindia Krishi Vishwavidyalaya, Gwalior (M.P.) during the year 2014-15. Guava plants were treated with zinc sulphate at 0.2 per cent, 0.3 per cent and 0.4 per cent and $\mathrm{GA}_{3}$ at $30 \mathrm{ppm}, 60 \mathrm{ppm}$ and $90 \mathrm{ppm}$ along with a control. Higher concentration of zinc sulphate $(0.40 \%)$ and $\mathrm{GA}_{3}(90$ ppm) spray enhanced the tertiary shoot length $(8.08 \mathrm{~cm})$, Shoot diameter $(4.26 \mathrm{~mm})$ and number of leaves per shoot (7.10). The maximum fruit set $(95.55 \%)$ and fruit retention $(77.48 \%)$ was recorded with higher dose of zinc sulphate and $\mathrm{GA}_{3}$. The higher dose of zinc sulphate and $\mathrm{GA}_{3}$ minimize the fruit drop (18.07\%). Maximum TSS (11.65) was recorded in higher dose of zinc sulphate and $\mathrm{GA}_{3}$. Minimum acidity $(0.20 \%)$ was recorded in higher dose.

KEY WORDS : Foliar spray, Zinc sulphate, $\mathrm{GA}_{3}$, Quality of guava

HOW TO CITE THIS ARTICLE : Jawed, Md., Lekhi, R., Vasure, N., Jatav, R. and Khan, S. (2016). Effect of foliar spray of zinc sulphate and gibberellic acid on growth and quality of guava G-27 (Psidium guajava L.). Asian J. Hort., 11(1) : 68-71, DOI : 10.15740/HAS/TAJH/11.1/68-71. 